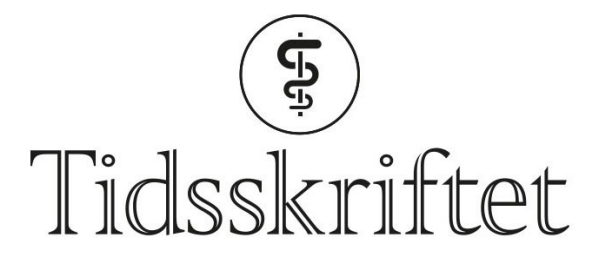

DEN NORSKE LEGEFORENING

\title{
Dødsfall i krigen i Syria tallfestet
}

FRA ANDRE TIDSSKRIFTER

KRISTOFFER BRODWALL

Barne- og ungdomsklinikken

Haukeland universitetssykehus

Krigen i Syria var en direkte årsak til nesten 150 ooo dødsfall de første seks årene, og over 100 ooo av ofrene var sivile.

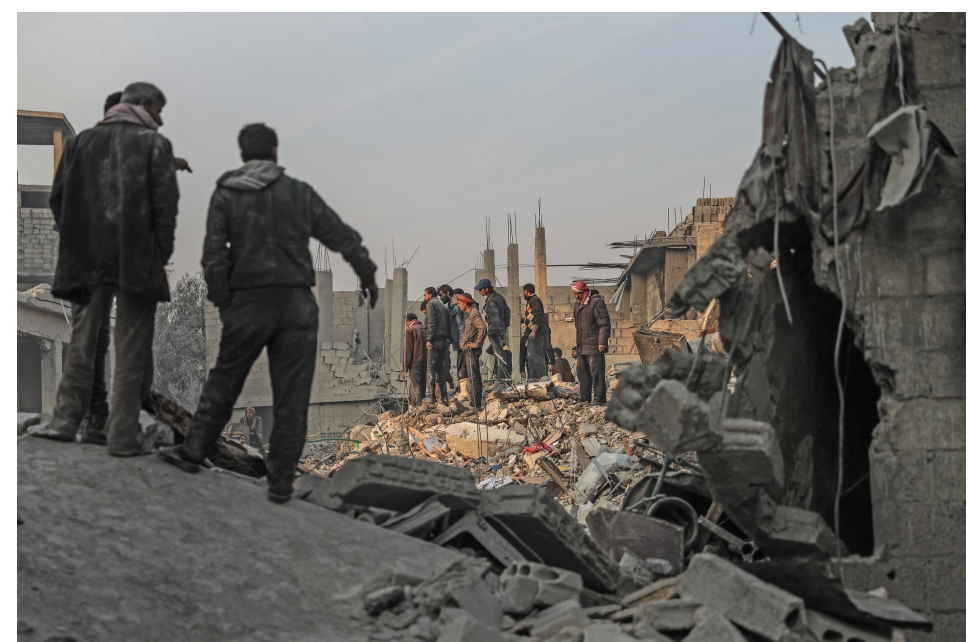

Sivile og medlemmer av De hvite hjelmene leter etter overlevende etter flybombing i Hamoria, alGhouta, Syria, 9.januar 2018. Foto: EPA / Mohammed Badra / NTB scanpix

Protestene mot regimet i Syria startet i mars 2011 og utviklet seg raskt til en krig som fortsatt pågår. Mer enn seks millioner mennesker har flyktet fra landet, og av dem som ble igjen har hundretusener dødd. Innen 2014 hadde den forventede levealderen for syrere falt med ca. 20 år.

Direkte dødsårsaker knyttet til krigen er skader etter voldsbruk og annen krigføring. I en ny studie er denne typen dødsfall blitt kartlagt og tallfestet (1). Studien omfattet alle voldelige dødsfall med komplett informasjon om sted, dato og dødsårsak for hele Syria, bortsett fra områder kontrollert av regjeringen.

I perioden fra 18. mars 2011 til 31. desember 2016 ble det registrert 143630 voldelige dødsfall, og $70,6 \%$ av de døde var sivile. Av de sivile døde var det en gradvis $\emptyset$ kende andel barn: $9 \% \mathrm{i}$ 2011, $19 \%$ i 2013 og $23 \%$ i 2016. Luftangrep og langdistanseprosjektiler forårsaket $57 \%$ av de sivile dødsfallene, inkludert $75 \%$ av dødsfall hos kvinner og $79 \%$ av dødsfall hos barn. Nesten alle dødsfall forårsaket av tønnebomber rammet sivile. Av ca. 20 ooo henrettelser gjaldt ca. $92 \%$ sivile.

Forfatterne bemerker at bruken av prosjektiler og luftangrep har tiltatt i løpet av krigen og 
er blitt den dominerende stridsformen, noe som har ført til svært mange sivile dødsfall. I tillegg har krigen indirekte forårsaket dødsfall gjennom økt sykdomsspredning, mangel på helsepersonell og annen ressursmangel.

LITTERATUR:

1. Guha-Sapir D, Schlüter B, Rodriguez-Llanes JM et al. Patterns of civilian and child deaths due to warrelated violence in Syria: a comparative analysis from the Violation Documentation Center dataset, 2011-16. Lancet Glob Health 2018; 6: e103 - 10. [PubMed][CrossRef]

Publisert: 15. januar 2018. Tidsskr Nor Legeforen. DOI: 10.4045/tidsskr.18.0040

(C) Tidsskrift for Den norske legeforening 2020. Lastet ned fra tidsskriftet.no 